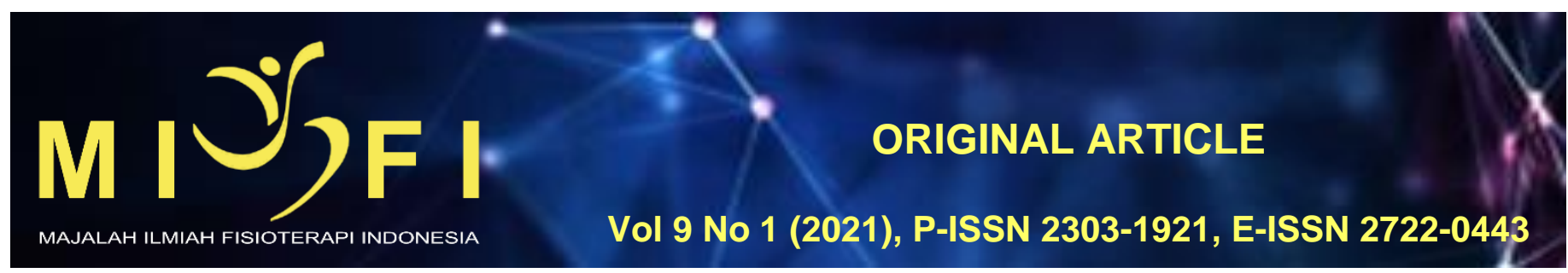

\title{
HUBUNGAN LAMA DURASI PENGGUNAAN MEDIA SOSIAL DENGAN KUALITAS TIDUR PADA USIA 19-22 TAHUN
}

\author{
Baiq Leny Suhartati ${ }^{1}$, Anak Ayu Nyoman Trisna Narta Dewi ${ }^{2}$, Ari Wibawa ${ }^{3}$, I Made Niko Winaya ${ }^{4}$ \\ ${ }^{1}$ Program Studi Sarjana Fisioterapi dan Profesi Fisioterapi, Fakultas Kedokteran, Universitas Udayana, Denpasar, Bali \\ 2,3,4 Departemen Fisioterapi, Fakultas Kedokteran, Universitas Udayana, Denpasar, Bali \\ baiqleny31@gmail.com
}

\begin{abstract}
ABSTRAK
Media sosial meningkatkan konektivitas antar individu sehingga memberikan peluang untuk memperoleh dan berbagi informasi. Pengguna internet tahun 2017 didominasi oleh usia 19-34 tahun dan merupakan masa mengembangkan diri dengan memperluas relasi sosial. Penggunaan media sosial yang intens dapat menyebabkan penggunanya merasakan kesenangan hingga tercandu dan membuat durasi penggunaan media sosial semakin lama sehingga menyebabkan terganggunya pengaturan hormon melatonin saat malam hari dan menyebabkan jam tidur lebih lama sehingga mempengaruhi kualitas tidur individu. Penelitian ini merupakan penelitian cross sectional analitik yang dilakukan pada bulan April hingga Mei 2019. Sampel penelitian diambil dengan teknik purposive dengan jumlah 46 sampel. Sampel mengisi kuesioner identitas dan data subyek serta kuesioner Pittsburg Sleep Quality Index (PSQI) untuk mengetahui durasi penggunaan media sosial perharinya dan kualitas tidur sampel. Analisis yang digunakan adalah analisis bivariat dengan uji spearman. Hasil analisis bivariat menunjukkan adanya hubungan yang signifikan $(p=0,037)$, tingkat kekuatan hubungan korelasi sedang $(r=0.308)$, dan hubungan bersifat searah $(r=0,308)$ antara durasi penggunaan media sosial dengan kualitas tidur. Penggunaan internet dan kecanduan media sosial dipengaruhi oleh keyakinan metakognitif tentang pemikiran dan pengaturan diri seseorang. Penggunaan media sosial yang intens dan kebiasaan membawa smartphone ketempat tidur membuat durasi penggunaan media sosial semakin lama sehingga menyebabkan terganggunya pengaturan hormon melatonin dan menyebabkan jam tidur lebih lama serta memengaruhi kualitas tidur individu. Simpulan dari penelitian ini adalah adanya hubungan lama durasi penggunaan media sosial dengan kualitas tidur pada usia 19-22 tahun yang mana semakin tinggi durasi penggunaan media sosial maka semakin buruk kualitas tidur pengguna.
\end{abstract}

Kata Kunci: durasi, kualitas tidur, media sosial

\section{THE RELATIONSHIP BETWEEN THE DURATION OF SOCIAL MEDIA USED WITH QUALITY OF SLEEP AGED 19-22 YEARS}

Social media increases connectivity between individuals that provides opportunities to obtain and share information. Internet users in 2017 dominated 19-34 years old and its time of self development by expanding social relations. Using social media intensely cause users feel pleasure until they addicted and trigger makes longer duration using social media so that disrupts melatonin hormone regulation at night and causes longer hours of sleep that affects quality of sleep. This research is cross sectional analytic study conducted from April to May 2019. The research sample was taken by purposive sampling technique with total 46 samples. Sample fills identity in questionnaire, subject data and Pittsburg Sleep Quality Index (PSQI) questionnaire to determine duration social media daily used and sleep quality. The analysis used bivariate analysis with Spearman test. The results of bivariate analysis showed there was significant relation $(p=0.037)$, level strength of correlation was moderate $(r=0.308)$, relation was unidirectional $(r=0.308)$ between duration of social media using with sleep quality. Internet use and social media addiction are influenced by metacognitive belief about thinking and self-regulation. The use of intense social media and the habit of carrying a smartphone to bed makes duration of social media use longer, causing disruption regulation of the hormone melatonin and causing longer hours of sleep, thereby affecting quality of individual sleep. Conclusion of this study is relation between duration using social media and sleep quality aged 19-22 years which higher duration using social media, the worse sleep quality of users.

Keyeord: duration, sleep quality, social media

\section{PENDAHULUAN}

Media sosial merupakan aplikasi yang paling diminati saat ini yang memfasilitasi pengguna terhubung dengan pengguna lainnya melalui internet sehingga memudahkan seseorang mendapatkan informasi ${ }^{1}$. Hasil survei APJII (Asosiasi Penyelenggara Jasa Internet Indonesia) menyatakan bahwa pada tahun 2017 pengguna internet di Indonesia mencapai 143,26 juta jiwa dari total penduduk 262 juta jiwa. Pengguna internet meningkat dibandingkan dengan tahun 2016 yang berjumlah 132,7 juta jiwa². Data dari Kominfo menyatakan total pengguna internet di Kota Denpasar mencapai 291.000 jiwa, dengan jumlah ini Kota Denpasar menduduki peringkat ke-12 pengguna internet tertinggi di Indonesia ${ }^{3}$. Mayoritas pengguna internet di Indonesia berdasarkan usia saat ini didominasi oleh usia berkisar 19-34 
tahun dengan jumlah $49,52 \%$ pengguna ${ }^{2}$. Usia tersebut sedang berada pada tahap intimacy yang berarti individu sedang mengembangkan diri dengan menjalin relasi sosial yang lebih luas baik secara langsung ataupun tidak langsung ${ }^{4}$. Media sosial yang saat ini memudahkan berkomunikasi begitu pula fiturnya semakin berkembang dan menarik membuat penggunanya rela menghabiskan waktu seharian untuk menjelajah media sosial bahkan hingga mengurangi waktu tidur.

Tidur sangat penting untuk fungsi otak, pembelajaran dan perhatian, kinerja sosial, kesejahteraan, dan kualitas hidup. Kurang tidur memiliki efek samping pada fungsi kognitif, temperamen, risiko kardiovaskular, metabolisme, berat badan, dan kekebalan tubuh ${ }^{5}$. Orang berpikir mengurangi waktu tidur tidak akan menimbulkan masalah, karena harus mengerjakan tanggung jawab lain yang jauh lebih penting, akan tetapi penelitian menunjukkan bahwa saat tidur organ vital bekerja untuk menjaga kesehatan tubuh dan berfungsi dengan baik ${ }^{6}$.

Kualitas tidur merupakan ukuran disaat seseorang mudah memulai tidur dan mempertahankan tidurnya. Kualitas tidur yang baik dapat dilihat dari kesehatan mental dan kebugarannya7. Faktor-faktor yang mempengaruhi kualitas tidur yaitu faktor fisiologis dan faktor psikologis. Faktor fisiologis dari kualitas tidur yang buruk yaitu adanya penurunan aktivitas, rasa lelah dan lemah, ketidakstabilan tanda vital tubuh, dan daya tahan tubuh yang menurun. Faktor psikologisnya yaitu berdampak depresi, sulit konsentrasi, dan cemas ${ }^{8}$.

Penelitian Syamsoedin, et al., mendapatkan hasil bahwa durasi penggunaan media sosial tertinggi yaitu kategori sedang (3-4 jam) dan kejadian insomnia terbanyak yaitu insomnia ringan sehingga hasilnya terdapat hubungan antara durasi penggunaan media sosial dengan kejadian insomnia ${ }^{9}$. Begitu pula dengan penelitian $\mathrm{Xu}$, et al., mendapatkan hasil bahwa lebih dari setengah mahasiswa sarjana memiliki kualitas tidur yang buruk. Penelitian ini menunjukkan situasi aktual mahasiswa terkait dengan frekuensi penggunaan media sosial, lebih dari setengah mahasiswa yang menggunakan media sosial memiliki kualitas tidur yang buruk ${ }^{10}$.

Sehubungan dengan adanya fitur media sosial yang semakin memudahkan seseorang dalam berkomunikasi sehingga adanya peningkatan durasi penggunaan media sosial dalam keseharian dan kualitas tidur amatlah penting yang berkaitan dengan kualitas hidup individu. Penelitian ini ingin mengetahui adanya hubungan lama durasi penggunaan media sosial dengan kualitas tidur. Penelitian ini juga diharapkan dapat meningkatkan pemahaman mengenai hubungan durasi penggunaan media sosial dengan kualitas tidur.

\section{METODE}

Rancangan yang digunakan dalam penelitian ini adalah observasional analitik dan menggunakan desain penelitian cross sectional. Penelitian ini dilakukan di Program Studi IImu Komunikasi Fakultas IImu Sosial dan IImu Politik Universitas Udayana yang telah dilaksanakan pada bulan April hingga Mei 2019. Teknik pengambilan sampel pada penelitian ini menggunakan teknik purposive sampling dan memenuhi kriteria inklusi ekslusi. Kriteria inklusinya yaitu mahasiswa Program Studi IImu Komunikasi Fakultas IImu Sosial dan IImu Politik Universitas Udayana yang usianya berkisar 19-22 tahun dan menggunakan media sosial minimal 1 tahun serta subjek dalam keadaan sehat sesuai dengan assessment vital sign yang dilakukan pada hari penelitian. Kriteria eksklusinya yaitu subjek rutin melakukan tidur siang atau interpretasi skor stress subjek pada kriteria sedang hingga sangat berat. Jumlah sampel yang didapatkan pada penelitian ini sejumlah 46 sampel penelitian. Variabel independen pada penelitian ini yaitu lama durasi penggunaan media sosial, variabel dependen pada penelitian ini yaitu kualitas tidur, variabel kontrol dalam penelitian ini adalah usia, psikologis tubuh, dan fisiologis tubuh, sedangkan variabel rambang pada penelitian ini adalah suhu lingkungan, lama waktu penggunaan media sosial, dan rutin tidur siang.

Pengukuran lama durasi penggunaan media sosial perharinya telah dikategorikan berdasarkan penelitian terdahulu yaitu $\geq 7$ jam dikategorikan sangat lama, 5-6 jam dikategorikan lama, 3-4 jam merupakan kategori sedang, 12 jam termasuk singkat, dan $<1$ jam kategori sangat singkat.

Ketepatan kualitas tidur individu dinilai menggunakan kuesioner Pittsburg Sleep Quality Index (PSQI). Kuesioner PSQI terdiri dari 19 pertanyaan dan digabung menjadi 7 komponen skor. Masing-masing komponen bernilai sama yaitu dari 0-3. Total skor dari 7 komponen yaitu berjumlah 21 . Kualitas tidur dikatakan baik jika skor $<5$ dan kualitas tidur buruk jika skor $>5$.

Analisa data yang digunakan pada penelitian ini yaitu analisis bivariat menggunakan Rho Spearman untuk melihat signifikansi, melihat kekuatan, dan melihat arah hubungan antar dua variabel. Analisis univariat untuk mengetahui data deskriptif dari masing-masing variabel.

Penelitian ini telah disetujui oleh Komisi Etik Penelitian Fakultas Kedokteran Universitas Udayana/Rumah Sakit Umum Pusat Sanglah Denpasar. Ethical clearance/keterangan kelaikan etik dengan nomor 1136/UN14.2.2.VII.14/LP/2019. Informed consent telah diperoleh dari sampel penelitian sebelum melakukan penelitian.

\section{HASIL \\ Karakteristik Sampel}

Tabel 1. Karakteristik Sampel

\begin{tabular}{lcc}
\hline \multicolumn{1}{c}{ Variabel } & Frekuensi (n) & Persentase (\%) \\
\hline $\begin{array}{l}\text { Jenis Kelamin } \\
\text { Laki-laki }\end{array}$ & 11 & \\
Perempuan & 35 & 23,9 \\
Usia & & 76,1 \\
19 & 25 & 54,3 \\
20 & 16 & 34,8 \\
21 & 3 & 6,5 \\
22 & 2 & 4,3
\end{tabular}


Durasi Penggunaan Media Sosial/hari

$\begin{array}{lcc}\text { Sangat singkat } & 0 & 0 \\ \text { Singkat } & 2 & 4,3 \\ \text { Sedang } & 12 & 26,1 \\ \text { Lama } & 14 & 30,4 \\ \text { Sangat Lama } & 18 & 39,1 \\ \text { Kualitas Tidur } & & \\ \text { Baik } & 7 & 15,2 \\ \text { Buruk } & 39 & 84,8 \\ \text { s Aplikasi Yang Digunakan } & & \\ \text { Instagram } & 42 & 0,91 \\ \text { Line } & 45 & 0,98 \\ \text { Youtube } & 41 & 0,89 \\ \text { WhatsApp } & 40 & 0,87 \\ \text { Facebook } & 16 & 0,35 \\ \text { Snapchat } & 1 & 0,09 \\ \text { Twitter } & 16 & 0,35 \\ \text { Ask.fm } & 0 & 0 \\ \text { Lainnya } & 5 & 0,11\end{array}$

Berdasarkan pemaparan Tabel 1., dapat dilihat bahwa sampel pada penelitian ini didominasi oleh sampel berjenis kelamin perempuan sejumlah 35 sampel (76,1\%). Sedangkan laki-laki yang hanya berjumlah 11 sampel $(23,9 \%)$.

Pada tabel diatas dapat dilihat bahwa usia sampel pada penelitian ini sudah berdasarkan kriteria inklusi dan ekslusi dan sebaran usia paling banyak pada usia 19 tahun dengan persentase $54,3 \%$, sedangkan sebaran usia paling sedikit pada usia 22 tahun $(4,3 \%)$.

Durasi penggunaan media sosial dalam sehari merupakan variabel bebas/independent pada penelitian ini dan telah dibagi berdasarkan kajian pustaka menjadi sangat singkat, singkat, sedang, lama, dan sangat lama. Pada tabel diatas dapat dilihat bahwa pengguna media sosial dengan kategori sangat lama merupakan kategori yang paling banyak digunakan yaitu sejumlah 18 sampel dengan persentase $39,1 \%$ sedangkan kategori durasi yang paling sedikit digunakan yaitu kategori sangat singkat dengan persentase $0 \%$.

Kualitas tidur merupakan variabel terikat/ dependent dari penelitian ini. Kualitas tidur dikatakan baik jika skor PSQI $<5$ dan kualitas tidur buruk jika skor $>5$. Semakin tinggi skor yang didapatkan maka semakin buruk kualitas tidur individu. Pada Tabel 1. dapat dilihat bahwa kualitas tidur kategori buruk lebih mendominasi sejumlah 39 sampel dengan persentase $84,8 \%$, sedangkan kualitas tidur kategori baik sejumlah 7 sampel dengan persentase $15,2 \%$.

Berdasarkan Tabel 1. dapat diketahui mayoritas media sosial yang digunakan oleh sampel adalah aplikasi line sejumlah 45 sampel dengan persentase $0,97 \%$, sedangkan aplikasi yang jarang digunakan sampel adalah Ask.fm dengan persentase $0 \%$. Sampel menggunakan lebih dari 1 aplikasi.

Tabel 2. Uji Spearman Durasi Penggunaan Media Sosial dengan Kualitas Tidur

\begin{tabular}{ccccc}
\hline & \multicolumn{3}{c}{ Rho Spearman } \\
\cline { 2 - 4 } & $\mathrm{p}$ & $\mathrm{r}$ & $\mathrm{n}$ \\
\hline $\begin{array}{c}\text { Durasi Penggunaan Media Sosial } \\
\text { Kualitas Tidur }\end{array}$ & 0,037 & 0,308 & 46 \\
\hline
\end{tabular}

Berdasarkan Tabel 2 dapat diketahui nilai signifikansi atau nilai $p$ sebesar 0,037 , karena nilai $p<0,05$ maka artinya ada hubungan yang signifikan (berarti) antara variabel lama durasi penggunaan media sosial dengan kualitas tidur. Dari output SPSS dengan uji spearman diperoleh angka koefisien korelasi sebesar 0,308 yang artinya tingkat kekuatan hubungan korelasi antara variabel lama durasi penggunaan media sosial dengan kualitas tidur adalah sebesar 0,308 atau korelasi sedang. Angka koefisien korelasi sebesar 0,308 sehingga hubungan kedua variabel tersebut bersifat searah (jenis hubungan searah), dengan demikian dapat diartikan bahwa semakin meningkatnya lama durasi penggunaan media sosial maka kualitas tidur semakin memburuk.

\section{DISKUSI}

\section{Karakteristik Sampel}

Karakteristik responden pada penelitian ini merupakan mahasiswa aktif Program Studi IImu Komunikasi Fakultas IImu Sosial dan IImu Politik Universitas Udayana yang berusia 19-22 tahun dan responden dipilih dengan menggunakan purposive sampling sejumlah 46 responden. Persebaran jenis kelamin responden dapat dilihat pada Tabel 1, penelitian ini didominasi oleh responden berjenis kelamin perempuan sebesar $76,1 \%$, sedangkan responden berjenis kelamin laki-laki sebesar $23,9 \%$. Jenis kelamin tidak berpengaruh besar pada penelitian ini karena penggunaan media sosial tidak memandang jenis kelamin.

Persebaran usia menunjukkan bahwa responden dengan usia 19 tahun merupakan usia responden yang mendominasi dibandingkan dengan usia lainnya yaitu sebesar $54,3 \%$. Sedangkan usia 20 tahun sebesar $34,8 \%$, usia 21 tahun sejumlah 6,5\%, dan usia 22 tahun sejumlah 4,3\%. Berdasarkan pendataan APJII (2017) pengguna internet di Indonesia didominasi oleh usia 19-34 tahun dengan persentase 49,52\% dan usia berkisar 18/20 - 25 tahun dikategorikan usia dewasa muda.

Durasi penggunaan media sosial perharinya didapatkan dari pertanyaan yang telah tercantum pada kuesioner identitas dan data subyek. Penelitian Syamsoedin, et al,. telah mengkategorikan durasi penggunaan media sosial 
perharinya menjadi 5 kategori yaitu $\geq 7$ jam dikategorikan sangat lama, 5-6 jam dikategorikan lama, 3-4 jam merupakan kategori sedang, 1-2 jam termasuk singkat, dan $<1$ jam kategori sangat singkat ${ }^{9}$. Pada penelitian ini pengguna media sosial terbanyak berada pada kategori durasi sangat lama yaitu sebanyak $39,1 \%$, sedangkan pengguna pada kategori durasi lama sejumlah 30,4\%. Sementara itu pengguna media sosial pada kategori sedang berjumlah $26,1 \%$, sedangkan pengguna kategori singkat sejumlah 4,3\% dan pada penelitian ini tidak ditemukan pengguna media sosial dengan durasi sangat singkat. Hal ini sejalan dengan penelitian Gulden \& Kubra yang berjudul "Relationship between Social Media Use and Sleep Quality in University Students" didapatkan hasil bahwa 96,6\% pemuda aktif menggunakan media sosial dan level penggunaan media sosialnya tinggi ${ }^{11}$.

Penelitian ini menganalisis adanya pengaruh antara lama durasi penggunaan media sosial dengan kualitas tidur. Kualitas tidur diukur menggunakan kuesioner Pittsburg Sleep Quality Index (PSQI). Berdasarkan pengukuran yang telah dilakukan, hasilnya dapat dilihat pada Tabel 1 yaitu dari 46 sampel didapatkan 39 sampel memiliki kualitas tidur yang buruk dengan persentase $84,8 \%$, sedangkan kualitas tidur baik hanya sejumlah 7 sampel dengan persentase $15,2 \%$.

\section{Hubungan Lama Durasi Penggunaan Media Sosial dengan Kualitas Tidur Pada Usia 19-22 Tahun}

Hubungan lama durasi penggunaan media sosial dengan kualitas tidur pada usia 19-22 tahun dapat diketahui dengan menggunakan uji spearman. Hasil analisis analitik menggunakan uji spearman dapat dilihat pada Tabel 2 , dapat diketahui nilai signifikansi atau nilai $p$ sebesar 0,037 , karena nilai $p<0,05$ maka artinya ada hubungan yang signifikan (berarti) antara variabel lama durasi penggunaan media sosial dengan kualitas tidur. Dari output SPSS dengan uji spearman diperoleh angka koefisien korelasi sebesar 0,308 yang artinya tingkat kekuatan hubungan korelasi antara variabel lama durasi penggunaan media sosial dengan kualitas tidur adalah sebesar 0,308 atau korelasi sedang. Angka koefisien korelasi sebesar 0,308 sehingga hubungan kedua variabel tersebut bersifat searah (jenis hubungan searah), dengan demikian dapat diartikan bahwa semakin meningkatnya lama durasi penggunaan media sosial maka kualitas tidur semakin memburuk.

Penelitian terdahulu juga telah membuktikan bahwa penggunaan media sosial dapat mempengaruhi jam tidur. Penelitian Syamsoedin, et al., mendapatkan hasil bahwa adanya hubungan antara durasi penggunaan media sosial dengan kejadian insomnia pada remaja dan dikatakan bahwa semakin tinggi penggunaan media sosial melalui laptop, komputer, tablet, ataupun ponsel seluler cenderung semakin mengganggu pengaturan hormon untuk tidur atau yang disebut hormon melatonin sehingga dapat menyebabkan semakin tingginya kejadian insomnia ${ }^{9}$. Begitu pula yang dikatakan $\mathrm{Xu}$, et al., bahwa adanya pengaruh penggunaan media sosial sebelum tidur dengan kualitas tidur. Studi mengatakan stimulasi cahaya biru pada malam hari berkaitan dengan kualitas tidur dan berefek pada fungsi siang hari, konsekuensi yang didapatkan yaitu menyebabkan efisiensi belajar yang rendah dan kelelahan jangka panjang. Sebagian besar responden mengalami kesulitan untuk bangun di pagi hari, mengalami kelelahan di tempat kerja, dan sering mengalami kekesalan. Kelelahan yang bersifat kronis dan perasaan kesal dapat menyebabkan terjadinya beberapa penyakit dan mengurangi kualitas hidup ${ }^{10}$.

Gulden \& Kubra menjelaskan bahwa terdapat beberapa mekanisme yang mendasari hubungan antara penggunaan media sosial dengan gangguan tidur. Pertama, pengguna media sosial dapat langsung menuju tempat tidur akan tetapi membutuhkan waktu untuk berhenti mengggunakan media sosial sebelum tidur sehingga periode tidur berkurang. Hal tersebut berkaitan dengan adanya kecemasan tentang menjauh dari interaksi sosial saat tidak terhubung dengan media sosial dan kecemasan ini mencegah waktu relaks sebelum tidur. Kedua, penggunaan media sosial dapat meningkatkan stimulasi emosional, kognitif dan/atau fisiologis. Ketiga, cahaya terang yang dipancarkan oleh perangkat untuk terhubung ke situs media sosial dapat menunda irama sirkadian. Selain itu, dikatakan mereka yang memiliki kesulitan tidur menemukan cara memulihkan diri dari masalah tidur yaitu dengan menggunakan media sosial. Kualitas tidur yang menurun menyebabkan peningkatan penggunaan media sosial yang memperburuk masalah tidur karena media sosial lebih menstimulasi minat semakin ingin menggunakan media sosial ${ }^{11}$.

Penggunaan internet dan kecanduan media sosial dipengaruhi oleh keyakinan metakognitif tentang pemikiran dan pengaturan diri seseorang (self-regulation). Model perilaku kognitif dan distorsi kognitif seperti gaya kognitif ruminatif merupakan penyebab utama penggunaan internet yang berlebihan. Distorsi kognitif secara otomatis akan diaktifkan setiap ada stimulus yang terkait dengan internet sehingga individu akan terus mengakses internet ${ }^{12}$.

Para ilmuwan telah mengusulkan teori neurobiologis untuk kecanduan internet. "Reward Center" atau "Pleasure Pathway" pada otak berhubungan dengan kesenangan yang dialami oleh seorang individu. Neurokimia yang terkait dengan kesenangan seperti dopamin, morfin, endorfin, dan lainnya dilepaskan ketika area otak seperti nucleus accumbens dari pleasure pathway diaktifkan. Zat kecanduan atau perilaku kecanduan mengaktifkan pleasure pathway di otak. Reseptor yang terlibat akan terpengaruh setiap terpapar dengan zat kecanduan atau perilaku kecanduan secara terus menerus ${ }^{13}$. Menurut beberapa studi neuroimaging, perubahan struktur otak dapat merusak fungsi eksekutif perencanaan dan penalaran, meningkatkan risiko impulsif dan membuat kecanduan. Beberapa studi melaporkan terdapat gangguan di daerah frontal otak terutama korteks dorsolateral prefrontal yang merupakan area bertanggung jawab untuk fungsi kognitif, motivasi, dan kontrol impuls ${ }^{14}$.

Prefrontal cortex dikaitkan dengan proses keinginan dalam kecanduan internet. Ketika seseorang dengan kecanduan internet diberikan sinyal terkait dengan jenis kecanduan yang dimiliki, prefrontal cortex akan menunjukkan peningkatan aktivitas. Prefrontal cortex juga bertanggung jawab untuk pengambilan keputusan. Individu dengan kecanduan akan merespon dengan cepat sinyal yang terkait dengan kecanduannya. Gejala penarikan sering terjadi setelah penghentian penggunaan internet. Gejala-gejalanya yang bisa dialami adalah gemetaran, mual, suhu tinggi, apatis atau kurang minat, dan masalah pencernaan. Hal tersebut dijelaskan karena meningkatnya kebutuhan akan dopamin di otak untuk membangun kembali keseimbangan kimianya. Karena itu, otak meminta lebih banyak stimulus perilaku untuk menciptakan tingkat kesenangan yang sama ${ }^{14}$. 
Retina memiliki fotoreseptor yang mengatur penglihatan dalam cahaya rendah (batang) serta merasakan warna (kerucut). Fotoreseptor ketiga telah diidentifikasi dan tidak berperan dalam persepsi visual tetapi lebih membantu mengatur ritme sirkadian. Sel-sel ini disebut intrinsically photosensitive retinal ganglion cells (ipRGCs) dan membentuk sekitar $1-2 \%$ dari sel fotoreseptor di retina yang sangat penting untuk menjaga sinkronisasi ritme sirkadian. Fotoreseptor khusus ini paling sensitif terhadap panjang gelombang cahaya yang lebih pendek (470 - $480 \mathrm{~nm}$ ), photopigment yang disebut melanopsin melakukan berbagai fungsi visual nonimage seperti kontrol sirkadian, suasana hati dan pembelajaran, pengaturan metabolisme, dan modulasi tidur. Setelah melanopsin diaktifkan, ipRGCs memberi isyarat pada suprachiasmatic nuclei (SCN) yang bertindak sebagai circadian pacemaker sehingga SCN menstimulasi kelenjar pineal dan menghambat pelepasan melatonin ${ }^{15}$.

Kelenjar pineal yang berada didalam otak mengatur produksi dan pengeluaran melatonin. Produksi melatonin dimulai segera setelah matahari terbenam, memuncak antara pukul 2-4 pagi, dan berhenti sekitar pukul 9 pagi. Hampir $80 \%$ melatonin diproduksi pada malam hari sedangkan siang hari produksi melatonin rendah. Setelah disintesis, melatonin dilepaskan ke dalam sirkulasi sistemik dan cerebral spinal fluid (CSF) dan terjadi proses modulasi seperti suasana hati, tidur, suhu tubuh, dan pola asupan makanan ${ }^{15}$.

Sekresi melatonin yang menunjukkan ritme sirkadian dapat ditekan oleh cahaya sedang atau terang terutama cahaya lampu biru dengan panjang gelombang $460 \mathrm{~nm}$ yang dapat diserap dengan baik oleh melanopsin yang terletak dalam sel neuro ganglia di retina. Layar smartphone, laptop, dan digital lain memancarkan cahaya biru (blue light) yang dapat menekan produksi hormon melatonin ${ }^{16}$. Produksi harian melatonin dapat ditekan dengan cepat oleh paparan cahaya biru karena panjang gelombang yang pendek (biru) lebih efektif dalam menginduksi respon ke retina daripada panjang gelombang yang panjang (warna merah ke kuning). Ritme sirkadian paling sensitif terhadap cahaya biru pada sekitar $450 \sim 470 \mathrm{~nm}$. Paparan cahaya biru dari semua jenis layar smartphone menekan melatonin. Mengendalikan sekresi melatonin merupakan faktor kunci dalam pengaturan kesehatan manusia dan ritme sirkadian ${ }^{17}$.

Penggunaan media sosial yang intens baik melalui smartphone ataupun laptop dapat menyebabkan penggunanya merasakan kesenangan hingga tercandu dan memicu penggunanya lebih intens menggunakan media sosial. Penggunaan media sosial yang intens dan kebiasaan membawa smartphone ketempat tidur membuat durasi penggunaan media sosial semakin lama sehingga menyebabkan terganggunya pengaturan hormon melatonin dan menyebabkan jam tidur lebih lama sehingga mempengaruhi kualitas tidur individu ${ }^{18}$.

Media sosial juga memiliki dampak baik ketika digunakan dengan tepat. Kebutuhan internet dapat meningkatkan keterampilan dan pengetahuan pelajar, media sosial juga dapat mendukung teknologi untuk berintegrasi secara efektif ke dalam berbagai lingkungan belajar, dan media sosial dapat mempengaruhi hubungan sosial dengan teman. Mengatur durasi dan waktu penggunaan media sosial dapat mencegah efek negatif dari penggunaan media sosial ${ }^{11}$.

Keunggulan dari penelitian ini yaitu dilakukan saat maraknya aplikasi media sosial yang semakin menarik sehingga dapat sembari memberikan edukasi pada masyarakat terutama mahasiswa serta penggunaan variabel media sosial mencakup luas dalam keseharian karena digunakan pada smartphone ataupun laptop, penelitian ini dapat dijadikan landasan teoritis untuk intervensi selanjutnya terutama intervensi yang berhubungan dengan fisioterapi, serta pada penelitian ini pengendalian faktor fisiologis tubuh dilakukan dengan pemeriksaan fisik secara objektif tiap individunya sehingga lebih meyakinkan pada tahap pengambilan sampel. Kelemahan dari penelitian ini adalah penulis tidak mengontrol suhu lingkungan serta pengukuran lama waktu penggunaan media sosial dan pengukuran tidur siang rutin masih dilakukan secara subjektif. Perbedaan penelitian ini dengan penelitian terdahulu antara lain yaitu pada penelitian terdahulu variabel yang digunakan adalah insomnia sedangkan pada penelitian ini menggunakan kualitas tidur yang berarti sampel penelitian cakupannya lebih luas karena untuk melihat kualitas tidur sampel tidak harus mengalami insomnia, penelitian terdahulu menggunakan kuesioner Insomnia Rating Scale sedangkan pada penelitian ini menggunakan Pittsburgh Sleep Quality Index, penjelasan mengenai mekanisme terjadinya hubungan penggunaan media sosial dengan kualitas tidur dijelaskan lebih rinci dan logis karena pembahasan mencakup kecanduan psikologis dan cahaya dari smartphone ataupun laptop sedangkan pada penelitian sebelumnya pembahasan mekanisme hubungan hanya sebatas karena cahaya dari smartphone, serta faktor-faktor yang memengaruhi kualitas tidur pada penelitian ini lebih dikontrol jika dibandingkan dengan penelitian sebelumnya. Kesamaan antara penelitian ini dan penelitian terdahulu yaitu menggunakan pendekatan cross sectional sehingga masih cukup terbatas dalam mengamati hubungan kedua faktor dengan baik.

\section{SIMPULAN}

Berdasarkan penelitian yang telah dilakukan mengenai hubungan lama durasi penggunaan media sosial dengan kualitas tidur pada usia 19-22 tahun di Program Studi IImu Komunikasi Fakultas Ilmu Sosial dan IImu Politik Universitas Udayana. Disimpulkan bahwa ada hubungan lama durasi penggunaan media sosial dengan kualitas tidur pada usia 19-22 tahun yang mana semakin tinggi durasi penggunaan media sosial maka semakin buruk kualitas tidur pengguna.

Diharapkan media sosial digunakan secara bijak yang berarti membatasi waktu penggunaan agar tidak mengganggu aktivitas sehari-hari. Menggunakan media sosial tidak disarankan menghabiskan waktu 2 jam penggunaan dalam sehari. Dianjurkan penggunaan media sosial dibatasi setengah jam hingga satu jam sehari. Untuk meminimalkan paparan dan efek radiasi. Jika melakukan percakapan panjang menggunakan smartphone yang harus dilakukan setiap hari, maka jarak yang ditempatkan antara tubuh dan sumber radiasi elektromagnetik harus dipertimbangkan sehingga akan membantu dalam meminimalkan tingkat paparan radiasi. Misalnya, dapat menggunakan headset dengan smartphone sehingga jarak antara tubuh dan smartphone tidak begitu dekat. Masyarakat diharapkan mengurangi penggunaan media elektronik pada malam hari untuk menghindari efek cahaya biru pada sekresi melatonin. Saat menggunakan media elektronik yang mengandung cahaya biru pada malam hari, 
disarankan menggunakan kacamata atau layar anti cahaya biru untuk menghindari cedera yang dapat disebabkan oleh cahaya biru. Contoh yang dapat digunakan yaitu antioxidant base scavengers, enzyme activity protectors, dan optic neuroprotective agents.

\section{DAFTAR PUSTAKA}

1. Jalonen, H., 2014. Social Media And Emotions In Organisational Knowledge Creation. Federated Conference on Computer Science and Information Systems, p. 1411-1419.

2. APJII, 2017. Penetrasi dan Perilaku Pengguna Internet Indonesia Tahun 2017. Teknopreneur.

3. Kominfo, 2013. Jumlah Pengguna Internet Berdasarkan Kota di Indonesia Tahun 2013. Data \& Statistik Kementrian Komunikasi dan Informatika RI.

4. Maheswari, J. \& Dwiutami, L., 2013. Pola Perilaku Dewasa Muda Yang Kecenderungan Kecanduan Situs Jejaring Sosial. Jurnal Penelitian dan Pengukuran Psikologi, 2(1).

5. Kaimal, D., Sajja, R. T. \& Sasangohar, F., 2017. Investigating the Effects of Social Media Usage on Sleep Quality. Human Factors and Ergonomics Society.

6. Institute, N. H. L. a. B., 2005. Your Guide To Healthy Sleep. Bethesda: NIH Publication.

7. Ohayon, M., Wickwire, E. M., Hirshkowitz, M., Albert, S. M., Avidan, A., Daly, F. J., Dauvilliers, Y., Ferri, R., Fung, C., Gozal, D., Hazen, N., Krystal. A., Lichstein, K., Mallampalli, M., Plazzi, G., Rawding R., Scheer, F. A., So mers, V \& Vitiello, M. V., 2017. National Sleep Foundation's sleep quality recommendations: first report. Journal of the National Sleep Foundation, Volume 3.

8. Jumiarni, 2018. Perbandingan Kualitas Tidur Menggunakan Skala Pittsburgh Sleep Quality Index (PSQI) Pada Pasien Gangguan Cemas Yang Mendapat Terapi Benzodiazepin Jangka Panjang dan Jangka Pendek. Konsentrasi Pendidikan Dokter Spesialis Terpadu.

9. Syamsoedin, W. K. P., Bidjuni, H. \& Wowiling, F., 2015. Hubungan Durasi Penggunaan Media Sosial dengan Kejadian Insomnia Pada Remaja Di SMA Negeri 9 Manado. ejournal keperawatan, Volume 3 (1).

10. Xu, X.-L., Zhu, R.-Z., Sharma, M. \& Zhao, Y., 2015. The Influence of Social Media on Sleep Quality: A Study of Undergraduate Students in Chongqing, China. J Nurs Care, 4(3).

11. Gulden, A. \& Kubra, Y., 2018. Relationship between Social Media Use and Sleep Quality in University Students. Sch. J. App. Med. Sci, 6(8), pp. 2960-2965.

12. Hou, Y., Xiong, D., Jiang, T., Song, L., \& Wang, Q. et al., 2019. Social media addiction: Its impact, mediation, and intervention. Journal of Psychosocial Research on Cyberspace, 13(1).

13. Ginige, P., 2017. Internet Addiction Disorder. INTECH.

14. Kurniasanti, K. S., Assandi, P., Ismail, R. I., Nasrun, M. W. S \& Wiguna, T., 2019. Internet addiction: a new addiction?. Medical Journal of Indonesia, 28(1), p. 82-91.

15. Culver, M. F., 2018. Sleep Interrupted: How Our Modern Life Affects Our Rhythm. EC Nutrition, pp. $250-259$.

16. Kawada, T., Kataoka, T., Tsuji, F., Nakade, M., Krejci, M., Noji, T., Takeuchi, H \& Harada, T., 2017. The Relationship between a Night Usage of Mobile Phone and Sleep Habit and the Circadian Typology of Japanese Students Aged 18 - 30 yrs. Scientific Research Publishing, Volume 8, pp. 892-902.

17. Oh, J. H., Yoo, H., Park, H. K. \& Do, Y. R., 2015. Analysis of Circadian Properties and Healthy Levels of Blue Light from Smartphones at Night. Scientific Reports.

18. Dewi, L. P., 2017. Hubungan Intensitas Penggunaan Situs Jejaring Sosial dengan Insomnia Pada Remaja di SMA Muhammadiyah 7 Yogyakarta. Fakultas IImu Kesehatan Universitas Aisyiyah Yogyakarta. 